\title{
Isolation of Pasteurella multocida during an Outbreak of Infectious Septicemia in Japanese Quail (Coturnix coturnix japonica)
}

\author{
Yoshitaka GOTO ${ }^{1)}$, Rie NAKURA ${ }^{1)}$, Tetsuo NASU ${ }^{2)}$, Takuo SAWADA ${ }^{3)}$ and Toshiharu SHINJO') \\ ${ }^{1)}$ Departments of Veterinary Microbiology and ${ }^{2)}$ Veterinary Anatomy, Miyazaki University, 1-1 Gakuen Kibanadai-Nishi, Miyazaki City, \\ Miyazaki 889-2192 and ${ }^{3)}$ Department of Veterinary Microbiology, Nippon Veterinary and Animal Science University, 1-7-1 Kyounan- \\ cho, Musasino City, Tokyo 180-0023, Japan
}

(Received 19 February 2001/Accepted 5 June 2001)

\begin{abstract}
In May 1994, about fifty Japanese quails out of ninety being bred for experimental purposes at Miyazaki University died of acute septicemia within a few days. At autopsy, there were no gross pathological lesions, however, severe bacteremia was observed in all cases. Bacterial examination revealed the presence of Pasteurella multocida in blood and several organs in pure culture and they were of Carter's capsular type A, Heddleston's type 3-4 and Namioka's type O-8-9. The $\mathrm{LD}_{50}$ of bacteria in quails and mice were 4.3 $\times 10^{4} \mathrm{cfu}$ and $3.9 \times 10^{2} \mathrm{cfu}$, respectively. All of the three chickens experimentally infected with $4 \times 10^{4}$ of the isolate died within 20 $\mathrm{hr}$ after the infection and several bacteria were recovered from their blood and organs. This, to our knowledge, is the first report on an outbreak of fowl cholera in Japanese quails in Japan.

KEY wORDS: Japanese quails, Pasteurella multocida, septicemia.
\end{abstract}

J. Vet. Med. Sci. 63(9): 1055-1056, 2001

Pasteurella multocida (P.multocida) infection, otherwise referred to as fowl cholera, is the causative agent of hemorrhagic septicemia in a broad spectrum of animal hosts, and avian pasteurellosis has been recognised as a worldwide disease for centuries. In Japan, the first report of fowl cholera, documented by Takaya et al. [19], was in myna birds (Eulabes intermedia) that had been imported from Thailand in 1976. Since then, fowl cholera has been reported in green pheasants [14], chickens [9], ducks [10], wild birds [4] and recently in turkeys [18]. However, there has been hitherto no report on this disease in quails. Here, we present a report on the first outbreak of fowl cholera caused by P.multocida in Japanese quails.

Ninety quails were reared for experimental use at Miyazaki University for 7 to 8 weeks under warm conditions $\left(20^{\circ} \mathrm{C}\right)$. Fifty quails died within a few days after they were taken outdoors. On these days the temperature was below $10^{\circ} \mathrm{C}$ and it was windy outside.

Autopsy of all dead or moribund quails was carried out. There were no gross lesions in moribund and dead cases, but microscopically, necrosis of liver cells and Gram-negative bacteria were found in heart, blood, liver, spleen and kidney samples of all cases. Many bipolar-staining bacilli associated with red blood cells or phagocytized by polymorphonuclear cells or monocytes were recognized in all these blood smear samples by Giemsa staining.

Blood samples of five moribund quails were subjected to bacterial isolation. Trypto-soya agar (TSA) (Nissui Seiyaku Co., Tokyo, Japan) was used for the isolation of aerobic bacteria and Gifu Anaerobic Medium (GAM) agar (Nissui Seiyaku Co., Tokyo, Japan) for the anaerobes. Horse blood was added to both TSA and GAM agar to give a final concentration of $3 \%$ before use. Anaerobic cultivation was performed by the steel wool method [1]. Identification of bacteria was done using Cowan's methods [2] and Bergey's manual for aerobes [6]. Non-sporeforming, Gram-negative short rods were isolated in pure culture from all blood examined under both aerobic and anaerobic conditions. The bacteria isolated by the two cultivation methods grew very well on the TSA supplemented with $3 \%$ horse blood but not on TSA alone or MacConkey agar aerobically. Five strains of bacteria were randomly selected and their biochemical properties were further determined. All strains produced acid by fermentation of glucose. They also reduced nitrate to nitrite and were catalase-positive, oxidase-positive and ornithine decarboxylase-positive, however the urease and ONPG test were negative. All of the five strains were identified as $P$. multocida. Next the serotype of three strains (two strains were lost by an unavoidable accident) were determined by the indirect hemagglutination test, as originally described by Carter [3] and later modified by Sawada et al. [16], using known antisera in which glutalaldehyde-fixed sheep erythrocytes were sensitized with extracts from the strain to be typed. The somatic antigen type was determined by the agar gel immunodiffusion precipitin test (Heddlestone's type) [5] and also by the $\mathrm{O}$ agglutination (Namioka's type) [16] tests. The serotypes of these three strains were the same and were identified as Carter's capsular type A, Heddleston's type 34 and Namioka's type O-8-9 [11].

Using twenty quails and twenty five mice, the lethal doses of the serotypes were determined. The animals were intravenously infected with various doses of bacteria and their survival times were recorded. Seven days later, survivors were sacrificed for pathological and bacteriological examinations. The $\mathrm{LD}_{50}$ of bacteria in quails and mice were estimated as $4.3 \times 10^{4} \mathrm{cfu}$ and $3.9 \times 10^{2} \mathrm{cfu}$, respectively. The quails challenged with lethal doses became dejected, were unable to move, had severe diarrhoea and died within twenty hours. Bacteria were recovered from all dead quails, but not from the blood of surviving quails except in one 
case. There were no gross lesions found in surviving or dead quails. All mice died within $15 \mathrm{hr}$ when they were challenged with lethal doses of bacteria and severe bacteremia was observed in blood of dead cases. However, neither bacteria nor pathological lesions were found in any organs of surviving mice.

To determine the virulence of the isolate, three chickens were experimentally infected with $4 \times 10^{4}$ bacteria. All chickens died within $20 \mathrm{hr}$ and several bacteria were recovered from their blood and organs.

The results presented indicate that the high mortality observed in quails is attributable to the P.multocida infection. Avian pasteurellosis has never been previously reported in and around Miyazaki. The source of the infection is therefore not yet known, but may presumably emanate from infected wild birds or rodents. Stress resulting from the movement of birds from a warm to a chilly place is considered to be the major trigger of the high sideration. Stress is reported to be an important predisposing factor in the pathogenesis of hemorrhagic septicemia of fowl cholera $[12,15]$. A lack of disinfection also appears to be a predisposing factor since no sudden death of quails occurred when their breeding room and its surroundings were disinfected.

Most of the P.multocida strains which have been isolated in Japan are of the Carter's capsular type A and Namioka's type O-8-9 [4, 7-9]. Our isolate in this case also seems to be of the same types. It appeared to be virulent as a result of the low lethal dose, and this is consistent with the report that Carter's capsular type A is pathogenic for chicken [7-9] and also predominates as a cause of fowl cholera [3]. Furthermore, Namioka's type $\mathrm{O}-8$ is also pathogenic as has been reported for Namioka's type O-5 [15]. The first case of isolation of type 5:A in Japan was reported in 1992 and it was found to be pathogenic for chickens [10]. Susceptibility to $P$. multocida infection is known to vary among animal species. It is considered that turkeys, geese and ducks have high susceptibility compared to chickens $[12,13,17,18]$. In chickens, virulence was observed to vary among different strains and ages $[12,17]$. This variation may be attributed to the differences in host resistance and serotypes isolated. The fact that all chickens died within a short time when they were challenged with $10^{4}$ bacteria suggests that our isolate may be pathogenic. Although there have been reported cases of pasteurellosis of quails in other parts of the world [17], this report represents the first recorded outbreak among Japanese quails.

ACKNOWLEDGEMENT. The authors are thankful to Mrs. H. Kiyoyama for her technical assistance.

\section{REFERENCES}

1. Azuma, R., Oogimoto, K. and Suto, T. 1962. Jpn. J. Bacteriol. 9: 802-806 (in Japanese).

2. Barrow, G. L. and R. K. A. Feltham, R. K. A. 1993. In: Manual for the Identification of Medical Bacteria 3th ed. (Barrow, G. I. and Feltham, R. K. A. eds.), Cambridge University Press, London.

3. Carter, G. R. 1955. Am. J. Vet. Res. 16: 481-484.

4. Fujihara,Y., Onai, M., Koizumi, S., Saito, N. and Sawada, T. 1986. Jpn. J. Vet. Sci. 48: 35-43.

5. Heddleston, K. L., Gallagher, E. and Rebers, P. A. 1972. Avian. Dis. 16: 925-936.

6. Holt, J. G., Kireg, N. R., Sneath, P. H. A., Staley, J. T. and Williams, S. T. 1994. Facultatively anaerobic gram-negative rods. pp. 175-289. In: Bergey's Manual of Determinative Bacteriology, 9th ed. (Holt, J. G., Kireg, N. R., Sneath, P. H. A., Staley, J. T. and Williams, S. T. eds.), Williams \& Wilkins, Baltimore, Maryland.

7. Inagaki, Y., Maeda, T., Ando, M., Nakamura, M., Kobayashi, M., Yoshida, K., Ootuka, M. and Sawada, T. 1986. J. Jpn. Soc. Poult. Dis. 22: 155-162 (in Japanese).

8. Kaige, N., Sugimoto, T., Sakakibara, H., Mori, M., Okamura, M., Nakayama, S. and Shoyama, S. 1990. J. Jpn. Soc. Poult. Dis. 26: 135-139 (in Japanese).

9. Komoda, M., Itoi, Y., Yamada, T., Nanzan, H., Mizutani, T. and Koizumi, S. 1989. J. Jpn. Soc. Poult. Dis. 25: 132-138 (in Japanese)

10. Nakamine, M., Ohshiro, M., Ameku, Y., Ohshiro, K., Keruma, T., Sawada, T. and Ezaki, T. 1992. J. Vet. Med. Sci. 54: 12251227.

11. Namioka, S. 1978. pp. 271-292. In: Methods in Microbiology, vol. 10 (Bergan, T. and Norris, J. R. eds), Academic Press, New York.

12. Rhoades, K. R. and Rimler, R. B. 1994. pp. 145-162. In: Disease of Poultry, 9th ed. (Calnec, B.W., Barnes,H.J., Beard, C.W., Reid, W.M. and Yoder, H.W. Jr. eds.), Iowa State University Press, Ames, Iowa.

13. Saitou, K., Morita, J., Senboku, T. and Sawada, T. 1993. J. Jpn.Vet. Med. Assoc. 46: 1001-1005 (in Japanese).

14. Sakurai, K., Kurihara, T., Matsuoka, T., Iijima, Y., Watanabe, F., Koeda, T. and Sawada, T. 1986. J. Vet. Med. Sci. 48: 711717.

15. Sawada, T. 1988. J. Jpn. Soc. Poult. Dis. 24: 99-110 (in Japanese).

16. Sawada, T., Rimler, R. B. and Rhoades, K. R. 1982. J. Clin. Microbiol. 15: 752-756.

17. Sawada, T., Rimler, R. B. and Rhoades, K. R. 1985. Am. J. Vet. Res. 46: 1247-1250.

18. Takai, H., Hayakawa, Y., Araya, E., Komae, H., Yoshida, Y., Ide, H., Abe, G. and Sawada, T. 1994 J. Jpn. Med. Assoc. 47: 923-927 (in Japanese).

19. Takaya, M., Akiyama, K., Taniguchi, T., Nonomura, I. and Horiuchi, T. 1981. Natl. Inst. Anim. Health Q. (Jpn.) 21: 129_ 133. 